\title{
RESPONSE OF POTATO PLANTS GROWN IN CLAY SOIL TO ANHYDROUS AMMONIA RATES AND FOLIAR APPLICATION OF ZN AND MN
}

\author{
Attef. A. El- Masry \\ Soils, Water and Environ. Res. Inst., Agric. Res. Centre, Giza, Egypt. \\ ABSTRACT
}

Two Field experiments on potato (Solanum tuberosum, L. cv. Diamont) crop were carried out at El-Qanater Horticultural Research Station, Kalubiya, Governorate, Egypt located at lat. 30.11, long 31.60 and $14.00 \mathrm{~m}$ above the mean sea level during two successive seasons 2010 and 2011. The study concerned the use of different rates of anhydrous ammonia (100 and $120 \mathrm{~kg} \mathrm{~N} / \mathrm{fed}$.) with foliar application of zinc and manganese or both on potato crop in alluvial soil. Generally, in most cases,

The high anhydrous ammonia level (120 kg N/ fed.) was increased significantly dry matter of potato plant at 90 days from planting and nitrogen \& phosphorus content as well as dry weight of tuber/ plant (g/plant), fresh \& dry tuber yield/fed., N, P, K, Zn and Mn contents of tuber compared to low anhydrous ammonia level $(100 \mathrm{~kg}$ $\mathrm{N} /$ fed.) of both seasons.

Generally, the most parameters in this investigation were increased significantly when the treatment of foliar application with mixture of $\mathrm{Zn}$ and $\mathrm{Mn}$ was carried out in both seasons. In contrast, the lowest ones were recorded by the control treatment (without foliar spray) followed by sole foliar spray with $\mathrm{Zn}$ or $\mathrm{Mn}$ in two seasons.

Finally, the best significant values of most parameters were obtained by interaction between foliar application with mixture of $\mathrm{Zn}$ and Mn under the high anhydrous ammonia level (120 kg N/ fed.). Meanwhile, the lowest ones were observed when control treatment (without foliar spray) with the low anhydrous ammonia level (100 kg $\mathrm{N} /$ fed.) was practiced of both seasons.

Key words: Potato, anhydrous ammonia, foliar application and yield productivity.

\section{INTRODUCTION}

In Egypt, potato (Solanum tuberosum, L.) is one of the most important and favorite vegetable crops grown. Its economic importance arises from the fact that large amount of this crop is exported yearly. Potato is a staple food in the diet of the world's population and also being used as animal feed (Dancs $\boldsymbol{e t}$ al., 2008). Although potato is considered as a starchy food, it is also included in the group of vegetables by its micronutrient content; Robert et al. (2006) suggested that expenditure of cooked potatoes (consumed with skin) may enhance antioxidant defense and improve the lipid metabolism, these effects could be interesting for prevention of cardiovascular diseases.

Nitrogen is the mineral nutrient most commonly deficient in agricultural soils (Foth and Ellis, 1996). As a result, farmers apply relatively high rates of $\mathrm{N}$ fertilizers. Soil-plant system inefficiencies prevent complete utilization of the $\mathrm{N}$, leaving residual $\mathrm{N}$ in the soil, which is a waste of natural resources and cause for environmental concern. Plants absorb $\mathrm{N}$ in the inorganic forms of nitrate $\left(\mathrm{NO}_{3}{ }^{-}\right)$and ammonium $\left(\mathrm{NH}_{4}{ }^{+}\right)$. Unfortunately, these forms can be lost

Fayoum J. Agric. Res. \& Dev., Vol. 26, No.2, July, 2012 
through conversion to nitrous oxide $\left(\mathrm{N}_{2} \mathrm{O}\right)$ (Ruser $\boldsymbol{e t}$ al., 1998 and Shoji, et al., 2001). A long-lived gas that is a source of nitric oxide (NO), that is thought to contribute to ozone $\left(\mathrm{O}_{3}\right)$ depletion in the stratosphere and increases in global temperatures (Isermann, 1994). In addition, the $\mathrm{NO}_{3}{ }^{-}$form is mobile and is potentially leached below the rooting zone to groundwater (Mueller and Dennis, 1996). Nitrogen can also move laterally to surface water (Randall and Mulla, 2001). At high concentration in drinking water, nitrate poses a potential health risk to humans and livestock and is also one of the contributing factors for eutrophication and hypoxia in surface waters (Goolsby et al., 2001, Rabalais et al., 2002 and Munoz et al., 2005). Nitrogen management is a high priority in potato cropping systems (Stark et al., 2004, and Westermann, 2005). Characteristically, $\mathrm{N}$ is the most limiting nutrient in crop production and is higher in concentration than all other mineral nutrients in most plants (Foth and Ellis, 1996). In potatoes, $\mathrm{N}$ rivals only $\mathrm{K}$ in highest mineral concentration (Stark et al., 2004, Munoz, et al., 2005 and Westermann, 2005). Potatoes are especially sensitive to $\mathrm{N}$ deficiencies and excesses (Stark et al., 2004). The necessity of $\mathrm{N}$ for growth has been demonstrated by several investigators, since nitrogen supply was desirable for vegetative growth, dry matter accumulation as well as nutrient uptake by potato plants (El- Ghamriny and Saeed, 2007). The increase in plant growth may be attributed to the beneficial effects of nitrogen on stimulating the merestimatic activity for producing more tissues and organs, since it plays major roles in the synthesis of structural proteins and other several macro molecules, in addition to its vital contribution in several biochemical processes that related to plant growth (Marschner, 1995). Also, nitrogen may be contributed with the activation of cell division and cell elongation (Medani $\boldsymbol{e t}$ al., 2000).

Micronutrients are required by plants in minute quantities, although these are very effective in regulating plant growth as they form a part of the enzyme system and thus regulate plant life. Pathak et al., (2011) and Soleymani and Shahrajabian, (2012) found that, Fe, $\mathrm{Zn}$ and $\mathrm{Mn}$ had positive effect on yield and quality of forage sorghum. The highest values of plant height, fresh forage yield, dry leaf and stem yield, total dry yield and dry leaf weight/dry stem weight was obtained by $\mathrm{Zn}+\mathrm{Fe}+\mathrm{Mn}$ application. In higher $\mathrm{pH}$ soil as that in Egyptian soils, it is known that micronutrients as well as some macronutrients may be limiting. Foliar products containing multi-nutrients may correct these deficiencies giving increases in growth and development. Foliar applications are often the most effective economical way to correct plant mineral deficiency (Kannan, 1986), especially when sink competition for carbohydrates between plant organs take place and nutrient uptake from the soil is restricted (Marschner, 1986). $\mathrm{Zn}$ and $\mathrm{Mn}$ elements have main role in synthesis of proteins, enzyme activating, oxidation and revival reactions and metabolism of carbohydrates. By utilizing of fertilizers contain above elements, performance on quality of crops is increasing and with shortage of this elements due to decline in plant photosynthesis and destroy RNA, amount of solution carbohydrates and synthesis of protein decreased and then performance and quality of crop will be decreased. Kelling and Speth (2001) reported that utilization of elements like $\mathrm{Zn}$ and $\mathrm{Mn}$ together from resource sulfate $\mathrm{Zn}$ and $\mathrm{Mn}$ increased efficiency and quality of potato crop. Mohamadi (2000) found that application of $\mathrm{Zn}$ along with $\mathrm{Mn}$ from foliar application caused increase in efficiency and quality of potato crop.

Fayoum J. Agric. Res. \& Dev., Vol. 26, No.2, July, 2012 
The present investigation was carried out to assess the efficacy of applying $\mathrm{N}$ fertilizer in the form of anhydrous ammonia associated with zinc and manganese as foliar application on potato yield and its components as well as its nutrients contents.

\section{MATERIALS AND METHODS}

Field experiments was carried out at El-Qanater Horticultural Research Station, Kalubiya, Governorate (located at lat. 30.11, long 31.60 and $14.00 \mathrm{~m}$ above the mean sea level) representing clay loam soil during the seasons 2010 \& 2011 to study the effect of ammonia gases levels with foliar spray by zinc or manganese or both on yield, its components as well as macro and micronutrients content in leaves at 90 days from planting and tuber at harvesting of potato crop.

Some physical and chemical properties of the tested soil which were measured and determined before planting according to Black (1982) and Ryan et al., (1996) were accessible in Tables 1 and 2.

Experiments were arranged in a split plot design with four replicates. The plot area was $21 \mathrm{~m}^{2}(4.2 \times 5)$ planted in ridges, $70 \mathrm{~cm}$ part, and $25 \mathrm{~cm}$ between plants in which the main treatments were devoted as anhydrous ammonia $(82 \% \mathrm{~N})$ at the rates 100 and $120 \mathrm{~kg} \mathrm{~N} / \mathrm{fed}$. The fertilizer was injection in the soil before cultivation about 8 days. While, the sub-ones included foliar applications of zinc or manganese or both. Micronutrients as an EDTA form were sprayed at a concentration of $0.06 \%$ twice, at 10 and 20 days after flowering.

A basal application of Phosphorus fertilizer was added at the rate of 75 $\mathrm{kg} \mathrm{P}_{2} \mathrm{O}_{5} / \mathrm{fed}$., as triple superphosphate $\left(37 \% \mathrm{P}_{2} \mathrm{O}_{5}\right)$ according to recommended dose by Ministry of Agriculture and Land Reclamation (Egypt). Meanwhile, $\mathrm{K}$ fertilizer was applied at the rate of $96 \mathrm{~kg} \mathrm{~K}_{2} \mathrm{O}$ as potassium sulphate. Phosphorus and Potassium fertilizers were applied with preparation of soil for cultivation.

Table (1) Physico - chemical properties of the soil

\begin{tabular}{|c|c|c|c|c|c|c|c|c|}
\hline \multirow{2}{*}{ Seasons } & \multicolumn{4}{|c|}{ Particle size distribution $(\%)$} & \multirow{2}{*}{$\frac{\mathbf{E C}_{\mathrm{e}}}{\left(\mathbf{d S m}^{-1}\right)}$} & \multirow{2}{*}{$\begin{array}{c}\text { pH } \\
(1: 2.5)\end{array}$} & $\mathrm{CaCO}_{3}$ & $\mathbf{O M}$ \\
\hline & Clay & Silt & Sand & Texture & & & \multicolumn{2}{|c|}{$\%$} \\
\hline 2010 & 31.4 & 33.5 & 35.1 & $\mathrm{CL}$ & 1.0 & 7.75 & 3.75 & 1.80 \\
\hline 2011 & 32.6 & 34.5 & 32.9 & CL & 1.10 & 7.80 & 3.60 & 1.65 \\
\hline
\end{tabular}

Table (2) Ionic properties of the soil

\begin{tabular}{|c|c|c|c|c|c|c|c|c|c|c|c|}
\hline \multirow{2}{*}{ Seasons } & $\mathbf{H C O}_{3}^{-}$ & $\mathbf{S O}_{4}{ }^{2-}$ & $\mathbf{C l}^{-}$ & $\mathbf{N a}^{+}$ & $\mathbf{K}^{+}$ & $\mathbf{C a}^{2+}$ & $\mathbf{M g}^{2+}$ & $\mathbf{N}$ & $\mathbf{P}$ & $\mathbf{K}$ \\
\cline { 2 - 10 } & \multicolumn{8}{|c|}{$\mathrm{M}$ mole L } \\
\hline 2010 & 3.65 & 2.56 & 4.00 & 4.20 & 0.31 & 2.97 & 2.73 & 38.50 & 9.12 & 193.30 \\
\hline 2011 & 3.75 & 2.78 & 4.20 & 4.42 & 0.49 & 2.94 & 2.88 & 37.00 & 10.15 & 190.40 \\
\hline
\end{tabular}

Potato (Diamant, cv.) were planted on $3^{\text {th }}$ and $6^{\text {th }}$ of February $2010 \&$ 2011, respectively and harvested at $27^{\text {st }}$ and $30^{\text {rd }}$ of May $2010 \& 2011$, respectively. Dry weight of above - ground plant parts /plant (g/plant) were measured in five plants at 90 days from planting. Dry weight of tuber/ plant (g/plant) was estimated at harvesting in five plants taken randomly from each treatment. Tuber fresh and dry (ton/ fed.) were also measured and recorded.

Plant samples after harvesting, dried at $70^{\circ} \mathrm{C}$; ground, digested and assigned for analyzing N, P, K, Zn and Mn. Nitrogen was determined using modified Kjeldahl method, phosphorous was determined colourimetrically

Fayoum J. Agric. Res. \& Dev., Vol. 26, No.2, July, 2012 
according to the procedure outlined by Ryan et al., (1996). Potassium was determined using the flame spectrophotometry method (Black, 1982). Zn and Mn were determined by using Atomic absorption.

The results were statistically analyzed using Mstat computer package to calculate $F$ ratio according to Snedecor and Cochran (1980). Least significant differences method (L.S.D) was used to differentiate means at the 0.05 level (Waller and Duncan, 1969).

\section{RESULTS AND DISCUSSION}

1. Dry matter as well as $N$ and $P$ content at 90 days from planting.

Data presented in Table (3) show that the high anhydrous ammonia level $(120 \mathrm{~kg} \mathrm{~N} /$ fed.) increased significantly dry matter leaves of potato at 90 days from planting as well as nitrogen and phosphorus content compared to low anhydrous ammonia level (100 kg N/ fed.) of both seasons. This can be attributed to increased vegetative growth of the potato plant by increasing nitrogen fertilizer rates. The current result is in consistent with the work of many researchers (Mahmoodabad et al., 2010) who had reported that an increase in nitrogen application increases dry matter. Also, nitrogen fertilizer plays an important role in canopy development especially on the shoot dry matter (Najm et al., 2010)

Table (3) Effect of foliar application of zinc and manganese or both under anhydrous ammonia rates on dry matter, $N$ and $P$ uptake of potato leaves at 90 days from planting in both seasons

\begin{tabular}{|c|c|c|c|c|c|c|c|c|c|}
\hline & \multicolumn{3}{|c|}{ Dry matter $(\mathrm{g}) /$ plant } & \multicolumn{3}{|c|}{$\mathrm{N}$ uptake(g)/ plant } & \multicolumn{3}{|c|}{ P uptake(g)/ plant } \\
\hline Treatments & $\mathrm{N}_{1}$ & $\mathrm{~N}_{2}$ & Mean & $\mathrm{N}_{1}$ & $\mathrm{~N}_{2}$ & Mean & $\mathrm{N}_{1}$ & $\mathrm{~N}_{2}$ & Mean \\
\hline \multicolumn{10}{|c|}{2010} \\
\hline Control & 37.60 & 45.70 & 41.65 & 1.620 & 1.723 & 1.672 & 0.132 & 0.150 & 0.141 \\
\hline Zinc & 39.50 & 48.63 & 44.07 & 1.780 & 1.880 & 1.830 & 0.099 & 0.112 & 0.106 \\
\hline Manganese & 42.63 & 51.60 & 47.12 & 1.983 & 2.130 & 2.057 & 0.158 & 0.178 & 0.168 \\
\hline $\mathrm{Zn}+\mathrm{Mn}$ & 44.03 & 65.90 & 54.97 & 2.033 & 2.350 & 2.192 & 0.162 & 0.196 & 0.179 \\
\hline Mean & 40.94 & $52.96^{*}$ & & 1.854 & $2.021 *$ & & 0.138 & $0.159 *$ & \\
\hline \multicolumn{10}{|l|}{ LSD at $5 \%$} \\
\hline Micronutrients & \multicolumn{3}{|c|}{1.077} & \multicolumn{3}{|c|}{0.08895} & \multicolumn{3}{|c|}{0.001258} \\
\hline Interaction & \multicolumn{3}{|c|}{1.523} & \multicolumn{3}{|c|}{ 0.1258 } & \multicolumn{3}{|c|}{$\mathbf{0 . 0 0 1 7 7 9}$} \\
\hline \multicolumn{10}{|c|}{2011} \\
\hline Control & 21.12 & 33.60 & 27.36 & 0.784 & 1.344 & 1.064 & 0.053 & 0.091 & 0.072 \\
\hline Zinc & 25.93 & 34.57 & 30.25 & 1.006 & 1.449 & 1.227 & 0.074 & 0.097 & 0.085 \\
\hline Manganese & 29.70 & 38.20 & 33.95 & 1.188 & 1.722 & 1.455 & 0.077 & 0.099 & 0.088 \\
\hline $\mathrm{Zn}+\mathrm{Mn}$ & 31.41 & 41.30 & 36.35 & 1.415 & 1.944 & 1.680 & 0.088 & 0.124 & 0.106 \\
\hline Mean & 27.04 & $36.92 *$ & & 1.098 & $1.615^{*}$ & & 0.073 & $0.103 *$ & \\
\hline \multicolumn{10}{|c|}{ LSD at $5 \%$} \\
\hline Micronutrients & \multicolumn{3}{|c|}{0.1591} & \multicolumn{3}{|c|}{0.03978} & \multicolumn{3}{|c|}{$\mathbf{0 . 0 0 1 2 5 8}$} \\
\hline Interaction & \multicolumn{3}{|c|}{0.2250} & \multicolumn{3}{|c|}{0.05626} & \multicolumn{3}{|c|}{0.001779} \\
\hline
\end{tabular}

$\mathrm{N} 1=100 \mathrm{~kg} \mathrm{~N} / \mathrm{fed}$ as anhydrous ammonia

$\mathrm{N} 2=120 \mathrm{~kg} \mathrm{~N} / \mathrm{fed}$ as anhydrous ammonia

Fayoum J. Agric. Res. \& Dev., Vol. 26, No.2, July, 2012 
Regarding the effect of sole foliar application by $\mathrm{Zn}$ and $\mathrm{Mn}$ or both on dry matter, $\mathrm{N}$ and $\mathrm{P}$ uptake of potato leaves at 90 days from planting, data tabulated in Table (3) reveal that the treatments of foliar spray by $\mathrm{Zn}$ and $\mathrm{Mn}$ as a mixed gave a highest significant values for all such parameters in both seasons. Meanwhile, the lowest ones were obtained with control treatment (without foliar spray) followed by sole application of $\mathrm{Zn}$ as a foliar in both seasons. Increasing such parameters due to $\mathrm{Zn} \& \mathrm{Mn}$ application may be attributed to enhanced photosynthesis activity which increased production and accumulation of carbohydrates and favorable effect on vegetative growth and macronutrients content. The obtained results are in good agreement with those obtained by Mona, Eleiwa et al. (2012) who found that when foliar nutritionals were used, the photosynthetic activity was stimulated, leading to enhancement of chemical constituents as crude protein, starch, carbohydrate, L-ascorbic acid and T.S.S in shoots which were afterwards translocated to the tubers. These effects may also due to the presence of micronutrients in the foliar compounds as $\mathrm{Zn}, \mathrm{Cu}, \mathrm{Mn}$ and $\mathrm{B}$.

With respect to the interaction between nitrogen fertilizer rates and foliar application of micronutrients on dray matter, $\mathrm{N}$ and $\mathrm{P}$ uptake of potato leaves at 90 days from planting, data show that the highest mean values of such parameters were obtained by foliar application of $\mathrm{Zn}$ and $\mathrm{Mn}$ together with the high level of anhydrous ammonia in both seasons. On the other hand, the lowest ones were observed when the control treatment (without foliar spray) under the low level of anhydrous ammonia was practiced in both seasons.

2. Potassium, Zinc and Manganese content at 90 days from planting.

Results in Table (4) illustrate that the treatment of $120 \mathrm{~kg} \mathrm{~N} / \mathrm{fed}$. gave the highest significant values of $\mathrm{K}$, and Mn content at 90 days compared with $100 \mathrm{~kg} \mathrm{~N} / \mathrm{fed}$. in both seasons. On the other hand, Zn content was affected significantly by anhydrous ammonia rates in second season only. Similar results were obtained by Stark et al. (2004) and Westermann (2005).

For the effect of foliar application of zinc and manganese or both on $\mathrm{K}$, $\mathrm{Zn}$ and Mn content of potato leaves at 90 days from planting, data reveal that, the same parameters were increased significantly by foliar spray with mixture $\mathrm{Zn}$ and $\mathrm{Mn}$ in both seasons. While, the lowest ones were recorded with control treatment (without foliar spray) followed by individual application of $\mathrm{Zn}$ in both seasons. These findings are in conformity with the observations of Pathak et al. (2011) and Soleymani and Shahrajabian (2012).

Respecting the interacted factors under study, results show that the foliar spray of $\mathrm{Zn}$ and $\mathrm{Mn}$ together under the high nitrogen level gave the highest significant values of all parameters in Table (4) in two seasons. Conversely, the lowest ones were recorded by the control treatment (without foliar spray) under the low level of anhydrous ammonia in both seasons.

Fayoum J. Agric. Res. \& Dev., Vol. 26, No.2, July, 2012 
Table (4) Effect of foliar application of zinc and manganese or both under anhydrous ammonia rates on $\mathrm{K}, \mathrm{Zn}$ and Mn uptake of potato leaves at 90 days from planting in both seasons

\begin{tabular}{|c|c|c|c|c|c|c|c|c|c|}
\hline \multirow{2}{*}{\begin{tabular}{|l|} 
\\
Treatments \\
\end{tabular}} & \multicolumn{3}{|c|}{ K uptake $(\mathrm{g}) /$ plant } & \multicolumn{3}{|c|}{ Zn uptake(g)/ plant } & \multicolumn{3}{|c|}{ Mn uptake(g)/ plant } \\
\hline & $\mathrm{N}_{1}$ & $\mathrm{~N}_{2}$ & Mean & $\mathrm{N}_{1}$ & $\mathrm{~N}_{2}$ & Mean & $\mathrm{N}_{1}$ & $\mathrm{~N}_{2}$ & Mean \\
\hline \multicolumn{10}{|c|}{2010} \\
\hline Control & 1.50 & 1.74 & 1.62 & 1.58 & 2.01 & 1.80 & 2.26 & 2.93 & 2.60 \\
\hline Zinc & 1.66 & 1.93 & 1.80 & 1.90 & 2.47 & 2.19 & 2.45 & 3.24 & 2.85 \\
\hline Manganese & 1.73 & 2.11 & 1.92 & 1.82 & 2.32 & 2.07 & 3.09 & 4.08 & 3.59 \\
\hline $\mathrm{Zn}+\mathrm{Mn}$ & 1.88 & 2.35 & 2.12 & 2.14 & 2.96 & 2.55 & 3.16 & 4.50 & 3.83 \\
\hline Mean & 1.69 & $2.03 *$ & & 1.86 & 2.44 & & 2.74 & $3.69 *$ & \\
\hline \multicolumn{10}{|c|}{ LSD at $5 \%$} \\
\hline Micronutrients & \multicolumn{3}{|c|}{0.056} & \multicolumn{3}{|c|}{0.040} & \multicolumn{3}{|c|}{0.040} \\
\hline Interaction & \multicolumn{3}{|c|}{0.080} & \multicolumn{3}{|c|}{0.056} & \multicolumn{3}{|c|}{0.056} \\
\hline \multicolumn{10}{|c|}{2011} \\
\hline Control & 0.65 & 1.22 & 0.93 & 0.70 & 1.35 & 1.02 & 1.40 & 2.39 & 1.89 \\
\hline Zinc & 0.86 & 1.31 & 1.09 & 0.98 & 1.59 & 1.28 & 1.75 & 2.52 & 2.14 \\
\hline Manganese & 0.95 & 1.38 & 1.17 & 1.07 & 1.68 & 1.38 & 2.14 & 3.05 & 2.59 \\
\hline $\mathrm{Zn}+\mathrm{Mn}$ & 1.07 & 1.65 & 1.36 & 1.32 & 2.07 & 1.69 & 2.36 & 3.47 & 2.91 \\
\hline Mean & 0.88 & $1.39 *$ & & 1.02 & $1.67 *$ & & 1.92 & $2.86 *$ & \\
\hline \multicolumn{10}{|c|}{ LSD at $5 \%$} \\
\hline Micronutrients & \multicolumn{3}{|c|}{0.040} & \multicolumn{3}{|c|}{0.040} & \multicolumn{3}{|c|}{0.040} \\
\hline Interaction & \multicolumn{3}{|c|}{0.056} & \multicolumn{3}{|c|}{0.056} & \multicolumn{3}{|c|}{0.056} \\
\hline
\end{tabular}

\section{Tuber weight/ plant, fresh and dry tuber yield of potato/fed.}

Data presented in Table (5) show the effect of micronutrients as foliar application and soil application of different $\mathrm{N}$ levels as anhydrous ammonia on tuber weight/ plant, fresh and dry tuber yield of potato/fed. grown in two seasons. Generally, the same trend almost of Tables (3\&4) was obtained in Table (5). The high level of anhydrous ammonia (120 kg N/fed.) gave a highest significant value of tuber weight/ plant, fresh and dry tuber yield of potato compared to other one in both seasons. The increase of potato tuber yield may be due to the helpful effects of nitrogen on motivating the merestimatic activity for producing more tissues and organs, because it plays main roles in the synthesis of structural proteins and other several macro molecules. Also, the current result is in consistent with the work of Zewide, et al. (2012) who concluded that different nitrogen rates have sound and promising impact on growth and marketable tuber yield of potato.

Parameters in Table (5) were increased significantly when the treatment of foliar application with $\mathrm{Zn}$ and $\mathrm{Mn}$ together was used in both seasons. In contrast, the lowest ones were observed by the control treatment (without foliar spray) followed by sole foliar spray with $\mathrm{Zn}$ or $\mathrm{Mn}$ in two seasons. This effect means that foliar nutrition application by $\mathrm{Zn}$ and $\mathrm{Mn}$ led to an increase in plant yield through dry matter accumulation in the economic parts of potato tuber. Results agree with El-Zeiny (2002) who found that vegetative growth, data affected by foliar compounds which in turn increased carbohydrate, cell division and enlargement leading to more yield.

Fayoum J. Agric. Res. \& Dev., Vol. 26, No.2, July, 2012 
Table (5) Effect of foliar application of zinc and manganese or both under anhydrous ammonia rates on tuber Weight/ plant, fresh and dry tuber yield of potato/fed. in both seasons

\begin{tabular}{|c|c|c|c|c|c|c|c|c|c|}
\hline \multirow{2}{*}{\begin{tabular}{|l|} 
\\
Treatments \\
\end{tabular}} & \multicolumn{3}{|c|}{ Tuber weight (g)/ plant } & \multicolumn{3}{|c|}{ Tuber yield (t/fed.) } & \multicolumn{3}{|c|}{$\begin{array}{c}\text { Tuber dry yield } \\
\text { (t/fed.) }\end{array}$} \\
\hline & $\mathrm{N}_{1}$ & $\mathrm{~N}_{2}$ & Mean & $\mathrm{N}_{1}$ & $\mathrm{~N}_{2}$ & Mean & $\mathrm{N}_{1}$ & $\mathrm{~N}_{2}$ & Mean \\
\hline \multicolumn{10}{|c|}{2010} \\
\hline Control & 542.4 & 611.9 & 577.2 & 9.319 & 10.11 & 9.72 & 1.76 & 1.96 & 1.86 \\
\hline Zinc & 634.3 & 714.7 & 674.5 & 10.32 & 11.30 & 10.81 & 2.13 & 2.16 & 2.15 \\
\hline Manganese & 667.2 & 754.0 & 710.6 & 11.10 & 11.72 & 11.41 & 2.20 & 2.30 & 2.25 \\
\hline $\mathrm{Zn}+\mathrm{Mn}$ & 704.8 & 772.3 & 738.6 & 11.70 & 12.31 & 12.01 & 2.24 & 2.41 & 2.33 \\
\hline Mean & 637.18 & $713.23^{*}$ & & 10.61 & $11.36^{*}$ & & 2.08 & $2.21 *$ & \\
\hline \multicolumn{10}{|c|}{ LSD at $5 \%$} \\
\hline Micronutrients & \multirow{2}{*}{\multicolumn{3}{|c|}{7.016}} & \multicolumn{3}{|c|}{0.154} & \multicolumn{3}{|c|}{0.080} \\
\hline Interaction & & & 9.922 & \multicolumn{3}{|c|}{0.218} & \multicolumn{3}{|c|}{0.113} \\
\hline \multicolumn{10}{|c|}{2011} \\
\hline Control & 231.2 & 242.7 & 236.9 & 6.41 & 6.72 & 6.57 & 1.54 & 1.54 & 1.54 \\
\hline Zinc & 257.8 & 324.3 & 291.0 & 6.80 & 7.54 & 7.17 & 1.61 & 1.77 & \begin{tabular}{|l|}
1.69 \\
\end{tabular} \\
\hline Manganese & 262.3 & 334.2 & 298.3 & 7.11 & 7.79 & 7.45 & 1.65 & 1.79 & 1.72 \\
\hline $\mathrm{Zn}+\mathrm{Mn}$ & 300.6 & 350.1 & 325.4 & 7.65 & 8.02 & 7.84 & 1.84 & 1.93 & 1.89 \\
\hline Mean & 262.98 & $312.82 *$ & & 6.99 & $7.52 *$ & & 1.66 & $1.76^{*}$ & \\
\hline \multicolumn{10}{|c|}{ LSD at $5 \%$} \\
\hline Micronutrients & \multirow{2}{*}{\multicolumn{3}{|c|}{$\frac{19.27}{27.25}$}} & \multicolumn{4}{|c|}{0.126} & \multicolumn{2}{|c|}{0.113} \\
\hline Interaction & & & & \multicolumn{4}{|c|}{0.178} & \multicolumn{2}{|c|}{0.159} \\
\hline
\end{tabular}

With regard to the interacted factors under this investigation, data show that the foliar application of $\mathrm{Zn} \& \mathrm{Mn}$ as mixture under the high level of nitrogen fertilizer gave the highest significant values of tuber weight/ plant, fresh and dry tuber yield of potato in two seasons. Whereas, the same trend was observed by sole foliar application of Mn under the high nitrogen rates on dry tuber yield of potato in two seasons, also, the individual foliar application of $\mathrm{Zn}$ or Mn with $120 \mathrm{~kg} \mathrm{~N} / \mathrm{fed}$., gave a high significant value of tuber weight/ plant in $2^{\text {nd }}$ season only. Otherwise, the lowest significant values of all parameters in Table (5) were recorded by the control treatment (without foliar spray) under $120 \mathrm{~kg} \mathrm{~N} / \mathrm{fed}$., in both seasons. While, the control treatment or sole foliar spray by $\mathrm{Zn}$ under the high level of nitrogen gave the same trend of tuber weight/ plant and dry tuber yield of potato in $2^{\text {nd }}$ season only. Potatoes require high amounts of fertilizer not only because of high nutrient demand, but also because they have a shallow, inefficient rooting system (Munoz et al., 2005 and Pack et al., 2006). Improvement in growth characters as a result of application of micronutrients might be due to the enhanced photosynthetic and other metabolic activity which leads to an increase in various plant metabolites responsible for cell division and elongation as opined by Hatwar et al. (2003). The photosynthesis enhanced in presence of zinc and boron was also reported by Rawat and Mathpal (1984). Mallick and Muthukrishnan (1979) explained that presence of zinc activates the synthesis of tryptophan, the precursor of IAA and it is responsible to stimulate plant growth.

Fayoum J. Agric. Res. \& Dev., Vol. 26, No.2, July, 2012 


\subsection{Nitrogen, $P$ uptake and starch of potato tuber}

Results in Table (6) illustrate that when nitrogen fertilizer rate was increased from 100 to $120 \mathrm{~kg} \mathrm{~N} /$ fed., the values of $\mathrm{N}$ and P uptake as well as starch percent of potato tuber were increased significantly in both seasons. This is due to the fact that, increased concentration of nitrogen fertilizer can increase the nitrogen and phosphorus uptake as well as starch percent of potato tuber and this increase has a positive effect on dry matter accumulation.

Foliar spray of $\mathrm{Zn}+\mathrm{Mn}$ as a mixture gave the highest values of $\mathrm{N}$ and $\mathrm{P}$ uptake in both seasons, while, starch percent was increased significantly by the same treatment in first one. Whereas, sole foliar application of Mn gave the highest significant value of starch \% in second season. On the other hand, the lowest significant values of $\mathrm{N}$ and $\mathrm{P}$ uptake as well as starch of potato tuber were obtained by the control treatment (without foliar spray) in both seasons. $\mathrm{P}$ uptake was decreased significantly by adding sole foliar application of $\mathrm{Zn}$ in two seasons.

Table (6) Effect of foliar application of zinc and manganese or both under anhydrous ammonia rates on $\mathrm{N}$ and $\mathrm{P}$ uptake as well as starch of potato tuber in both seasons

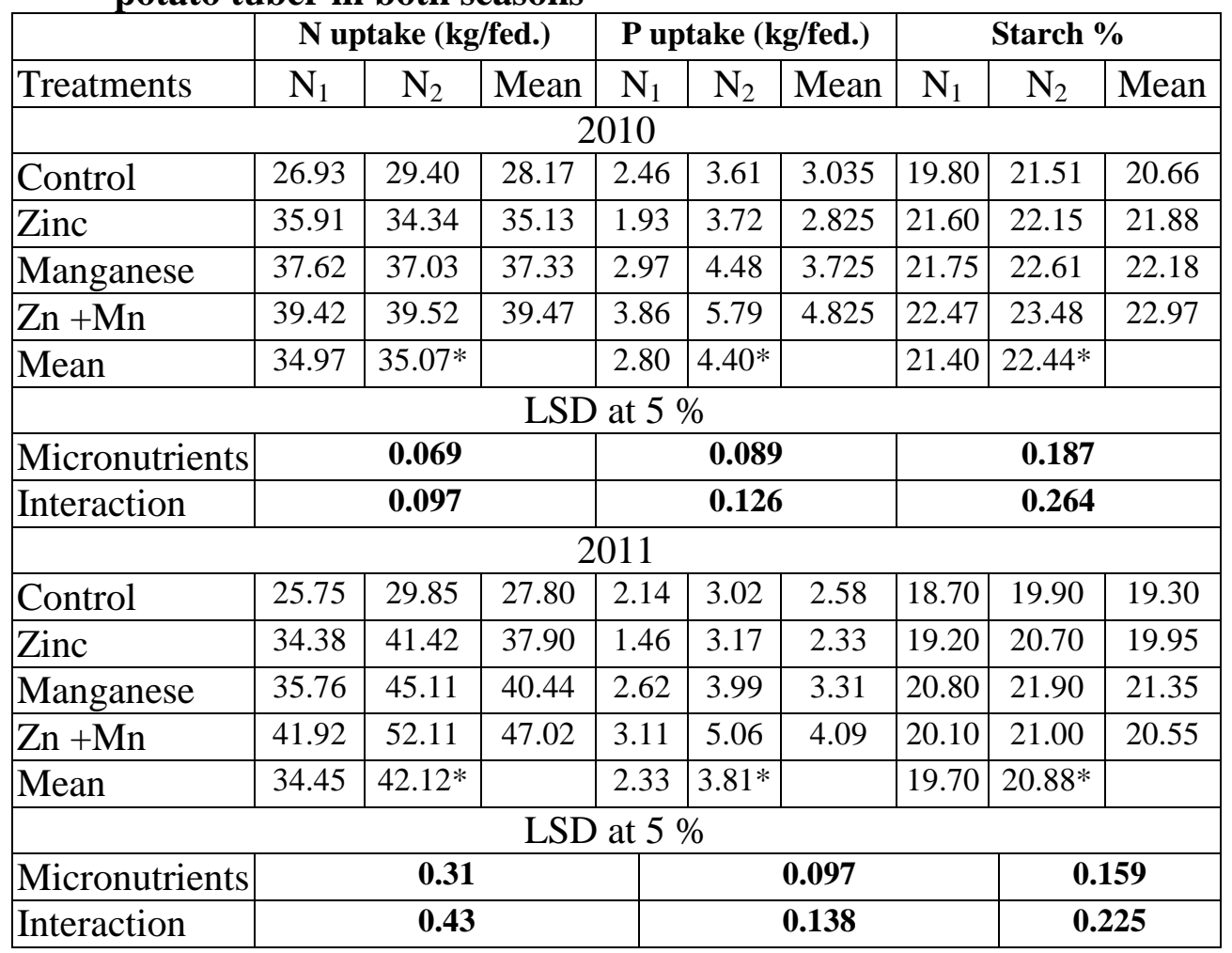

Concerning the interacted factors under this study on $\mathrm{N}$ and $\mathrm{P}$ uptake as well as starch of potato tuber, data tabulated in Table (6) reveal that the best significant values of such parameters were observed when foliar spray mixture of $\mathrm{Zn} \& \mathrm{Mn}$ with the high nitrogen fertilizer rates was practiced in both seasons. With one exception, starch percentage of tuber yield was increased significantly by foliar application of $\mathrm{Mn}$ alone under $120 \mathrm{~kg} \mathrm{~N} / \mathrm{fed}$., in the $2^{\text {nd }}$ one only. Vis versa, the control treatment (without foliar spray) beneath the low nitrogen level gave the lowest significant values of $\mathrm{N}$ uptake and starch \%

Fayoum J. Agric. Res. \& Dev., Vol. 26, No.2, July, 2012 
of potato tuber in both seasons. In addition to the foliar application of $\mathrm{Zn}$ alone under $100 \mathrm{~kg} \mathrm{~N} / \mathrm{fed}$., was significantly decreased P uptake in both ones.

\section{5. $\mathrm{K}, \mathrm{Zn}$ and Mn uptake of potato tuber}

Statistical analysis for results presented in Table (7) show that the high nitrogen fertilizer level was superior to the lowest one; the highest significant values of $\mathrm{K}, \mathrm{Zn}$ and $\mathrm{Mn}$ uptake of potato tuber were recorded by $120 \mathrm{~kg}$ $\mathrm{N} /$ fed., while the lowest ones were obtained by $100 \mathrm{~kg} \mathrm{~N} / \mathrm{fed}$., in both seasons.

With reference to the effect of foliar application of zinc and manganese or both under anhydrous ammonia rates on $\mathrm{K}, \mathrm{Zn}$ and $\mathrm{Mn}$ uptake of potato tuber, data reveal that the foliar spray of potato plants by mixture of $\mathrm{Zn} \& \mathrm{Mn}$ significantly increased such parameters in both seasons. Meanwhile, the control treatment (without foliar spray) gave the lowest significant ones in both seasons.

Table 7 Effect of foliar application of zinc and manganese or both under anhydrous ammonia rates on $\mathrm{K}, \mathrm{Zn}$ and Mn uptake of potato tuber in both seasons

\begin{tabular}{|c|c|c|c|c|c|c|c|c|c|}
\hline \multirow{2}{*}{ Treatments } & \multicolumn{3}{|c|}{ K uptake (kg/fed.) } & \multicolumn{3}{|c|}{ Zn uptake (g/fed.) } & \multicolumn{3}{|c|}{ Mn uptake (g/fed.) } \\
\hline & $\mathrm{N}_{1}$ & $\mathrm{~N}_{2}$ & Mean & $\mathrm{N}_{1}$ & $\mathrm{~N}_{2}$ & Mean & $\mathrm{N}_{1}$ & $\mathrm{~N}_{2}$ & Mean \\
\hline \multicolumn{10}{|c|}{2010} \\
\hline Control & 30.80 & 39.52 & 35.16 & 61.60 & 72.16 & 66.88 & 106.3 & 119.7 & 113.0 \\
\hline Zinc & 40.25 & 44.25 & 42.25 & 77.89 & 93.81 & 85.85 & 115.9 & 141.5 & 128.7 \\
\hline Manganese & 40.59 & 44.75 & 42.67 & 70.95 & 85.92 & 78.43 & 128.7 & 148.6 & 138.6 \\
\hline $\mathrm{Zn}+\mathrm{Mn}$ & 49.86 & 55.54 & 52.70 & 92.00 & 113.9 & 102.9 & 152.4 & 183.4 & 167.9 \\
\hline Mean & 40.38 & $46.02 *$ & & 75.61 & 91.44* & & 125.82 & $148.29 *$ & \\
\hline \multicolumn{10}{|c|}{ LSD at $5 \%$} \\
\hline Micronutrients & \multirow{2}{*}{\multicolumn{3}{|c|}{$\frac{0.21}{0.30}$}} & \multirow{2}{*}{\multicolumn{3}{|c|}{$\frac{0.81}{1.14}$}} & \multicolumn{3}{|c|}{0.41} \\
\hline Interaction & & & & & & & & 0.58 & \\
\hline \multicolumn{10}{|c|}{2011} \\
\hline Control & 26.30 & 34.60 & 30.45 & 59.75 & 72.13 & 65.94 & 104.6 & 112.6 & 108.6 \\
\hline Zinc & 37.74 & 42.12 & 39.93 & 78.56 & 93.79 & 86.18 & 115.6 & 139.4 & 127.5 \\
\hline Manganese & 36.78 & 41.16 & 38.97 & 69.47 & 84.12 & 76.80 & 119.3 & 141.7 & 130.5 \\
\hline $\mathrm{Zn}+\mathrm{Mn}$ & 43.55 & 50.95 & 47.25 & 91.14 & 112.66 & 101.90 & 152.4 & 184.6 & 168.5 \\
\hline Mean & 36.09 & $42.21^{*}$ & & 74.73 & $90.68^{*}$ & & 122.98 & $144.58^{*}$ & \\
\hline \multicolumn{10}{|c|}{ LSD at $5 \%$} \\
\hline Micro & \multirow{2}{*}{\multicolumn{3}{|c|}{$\frac{0.3280}{0.4639}$}} & & & & \multirow{2}{*}{\multicolumn{3}{|c|}{\begin{tabular}{|l|}
0.4707 \\
0.6656
\end{tabular}}} \\
\hline Interaction & & & & \multicolumn{3}{|c|}{$\begin{array}{l}0.0141 \\
0.7270\end{array}$} & & & \\
\hline
\end{tabular}

Regarding the interaction effect between anhydrous ammonia fertilizer rates and foliar spray of zinc and manganese or both on K, Zn and Mn uptake of potato tuber; data in Table (7) show that the treatment of foliar application by mixture of $\mathrm{Zn} \& \mathrm{Mn}$ under the high nitrogen fertilizer level increased significantly the studied parameters in both seasons. On the other hand, the lowest ones were obtained when control (without foliar spray) under the low nitrogen level was applied in both seasons.

\section{Conclusion}

Potato is sensitive to nitrogen fertilizer, consequently has become an essential component of potato production. Also, increased yield due to micronutrients application may be attributed to enhancing photosynthesis activity, increasing production and accumulation of carbohydrates and favorable effect on vegetative growth and retention of potato tuber yield.

Fayoum J. Agric. Res. \& Dev., Vol. 26, No.2, July, 2012 
Therefore, it is recommended that potato $\mathrm{cv}$. Diamant should be fertilized with (120 N kg/fed., and foliar application by mixture of $\mathrm{Zn} \mathrm{\&} \mathrm{Mn)} \mathrm{to} \mathrm{achieve} \mathrm{the}$ optimum quantity and quality of tuber yield.

\section{REFERENCES}

Black, C.A. (1982). Methods of soil analysis. Part 2. Chemical and microbiological properties. Second Edition. Amer. Soc. of Agron. Madison, Wisconsin, U.S. A.

Dancs, G., Mihaly, K. and Zsofla, B. (2008). The effect of enhanced methionine synthesis on amino acid and anthocyanin content of potato tubers. BMC Plant Biol., 8: 65.

El-Ghamriny, E.A. and Saeed, M.N.A. (2007). Effect of irrigation intervals, Mineral fertilizers and biofertilizers on potato plants grown under sandy soil conditions. I-Growth, water relations, chemical contents and leaf anatomy. Egypt. J. Appl. Sci., 22: 480-511.

El-Zeiny, O.A.H. (2002). Using tissue culture as a tool for increasing the productivity of seedlings and total yield of some pepper hybrids. Ainshams Univ. Cairo Arab Univ. J. Agric. Sci., 10: 273-285.

Foth, H.D. and Ellis, B.G. (1996). Soil Fertility, 2nd Ed. CRC Press, Boca Raton, FL.

Goolsby, D.A., Battaglin, W.A., Aulenbach, B.T., and Hooper, R.P. (2001). N input to the Gulf of Mexico. J. Environ. Qual. 30:329-336.

Hatwar, G.P. Gondane, S.V. Urkude, S.M. and Gahukar, O.V. (2003). Effect of micronutrients on growth and yield of chilli. Soi. Crop., 13:123-1254.

Isermann, K. (1994). Agriculture's share in the emission of trace gases affecting the climate and some cause-oriented proposals for sufficiently reducing this share. Environ. Pollut. 83:41-56.

Kannan S. (1986). Foliar absorption and transport inorganic nutrients. CRC Crit. Rev. Plant Sci. J., pp. 341-375.

Kelling, K.A. and Speth, P.E. (2001). Effect of micronutrient on potato tuber yield and quality at Spooner, University of Wisconsin-Madis.

Mahmoodabad, R., Somarin, S., Khayatnezhad, M. and Roza, G. (2010). Quantitative and qualitative yield of potato tuber by used of nitrogen fertilizer and plant density. Am.-Eur. J. Agric. Environ. Sci., 9: 310318.

Mallic, M.F.R. and Muthukrishnan, C.R. (1979). Effect of micronutrients on tomato (Lycopersicon esculentum Mill). 1: Effect on growth and development. Sou, Ind. Hort., 27:121-124.

Marschner, H. (1986). Mineral nutrition in higher plants. Academic Press New York, 564

Marschner H. (1995). Mineral nutrition of higher plants. $2^{\text {nd }} E d$. Academic. Press. London, New York, p. 889.

Medani R.A., Mohamed, S.A., El-Yazal, M.A. and Mahfouz, S.A. (2000). Growth, Yield and chemical composition of sugar beat as affected by specific isolated biofertilizers in relation on nitrogen application. Annals Agric. Sci. Moshtohor, 38 (4): 2019-2038.

Mohamadi, E. (2000). Study Effects of nutrient elements utilization methods ( $\mathrm{Zn}, \mathrm{Mn}$ and $\mathrm{Mg}$ ) on increase performance quantitative and quality of two potato species. Jehad and Agriculture Ministry, Final Report of Research Institute Reformand Providing Sapliny and Seed.

Fayoum J. Agric. Res. \& Dev., Vol. 26, No.2, July, 2012 
Mona, E. Eleiwa, Ibrahim, S.A. and Manal, F. Mohamed, (2012). Combined effect of NPK levels and foliar nutritional compounds on growth and yield parameters of potato plants (Solanum tuberosum L.). Afr. J. Microbiol. Res. 6: 5100-5109

Mueller, D.K. and Dennis, R.H. (1996). Nutrients in the nation's water supply: Too much of a good thing? US Geolog. Survey Circ. No. 1136. US Dept. of the Interior, Washington, DC.

Munoz, F., Mylavarapu, R.S., and Hutchinson, C.M. (2005). Environmentally responsible potato production systems: A review. J. Plant Nutr., 28:1287-1309.

Najm, M., Fazeli, R., Taghi, F. and Shamorady, M. (2010). Effect of utilization of organic and inorganic nitrogen source on the potato shoots matter, leaf area index and plant height, during middle stage of growth. Int. J. Agric. Biol. Sci., 1: 1-1.

Pack, J.E., Hutchinson, C.M., and Simonne, E.H. (2006). Evaluation of controlled-release fertilizers for northeast Florida chip potato production. J. Plant Nutr. 29:1301-1313.

Pathak, M., Bauri, F.K., Misra, D.K., Bandyopadhyay, B. and Chakraborty, K. (2011). Application of micronutrients on growth, yield and quality of banana. Journal of Crop and Weed, 7(1), 52-54.

Rabalais, N.N., Turner, R.E., and Scavia, D. (2002). Beyond science into policy: Gulf of Mexico hypoxia and the Mississippi River. BioScience, 52:129-142.

Randall, G.W., and Mulla, D.J. (2001). Nitrate nitrogen in surface waters as influenced by climatic conditions and agricultural practices. J. Environ. Qual. 30:337-344.

Rawat, P.S. and Mathpal, K.N., (1984). Effect of micronutrients on yield and sugar metabolism of some of the vegetables under Kumaon hill conditions. Sci. Cult., 50:243-244.

Robert, L., Agnes, N., Edmond, R., Chistian, D., Anderzej, M. and Christain, R. (2006). Entire potato consumption improves lipid metabolism and antioxidant status in cholesterol - Fed rat. Eur. J. Nutr., 45:267-274.

Ruser, R., Flessa, H., Schilling, R., Steindl, H., and Beese, F. (1998). Soil compaction and fertilization effects on nitrous oxide and methane fluxes in potato fields. Soil Sci. Soc. Am. J. 62:1587-1595.

Ryan J, Garabet S, Harmsen K, and Rashid A. (1996). Soil and plant analysis manual. Adapted for the West Asia and North Africa Region. Intl Center Agric. Res. in the Dry Areas ICARDA, Aleppo, Syria, p. 140.

Shoji, S., Delgado, J., Mosier, A., and Miura, Y. (2001). Use of controlled release fertilizers and nitrification inhibitors to increase nitrogen use efficiency and to conserve air and water quality. Commun. Soil Sci. Plant Anal. 32:1051-1070.

Snedecor, G.W. and Cochran, W.G. (1980). One way classification-Analysis of Variance - The random effect model- Two way Classification (Eds) In Statistical Methods. The lowas State Univ. Press Ames lowa USA : 215-273.

Soleymani, A. and Shahrajabian, M.H. (2012). The Effects of Fe, Mn and Zn Foliar Application on Yield, Ash and Protein Percentage of Forage Sorghum in Climatic Condition of Esfahan. International Journal of

Fayoum J. Agric. Res. \& Dev., Vol. 26, No.2, July, 2012 
Biology; 4: 92-96.

Stark, J.C., Westermann, D.T. and Hopkins, B.G. (2004). Nutrient management guidelines for Russet Burbank potatoes. Bull. 840. Univ. of Idaho, Moscow.

Waller, R.A. and Duncan, C.B. (1969). Abays rule for symmetric multiple comparison problem Amer. State Assoc. Jour. 12: 1485-1503.

Westermann, D.T. (2005). Nutritional requirements of potatoes. Am. J. Potato Res., 82:301-307.

Zewide, I., Mohammed, A. and Tulu, S. (2012). Effect of Different Rates of Nitrogen and Phosphorus on Yield and Yield Components of Potato (Solanum tuberosum L.) at Masha District, Southwestern Ethiopia. International J. Soil Sci. 7: 146-156.

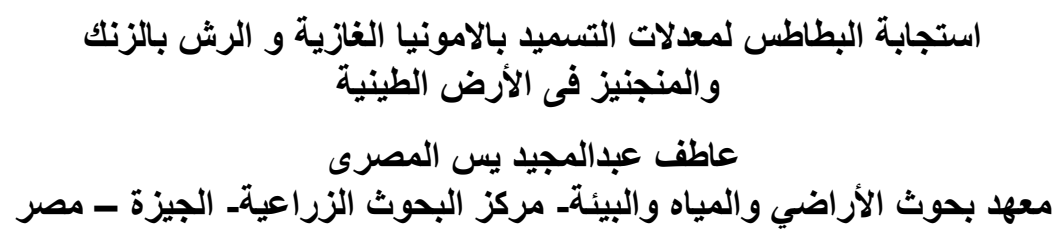

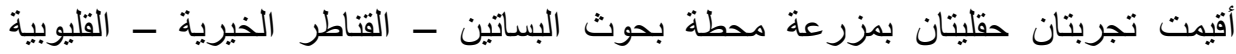

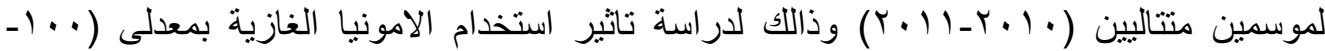

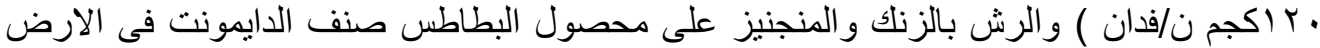

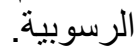

وقد اوضحت النتائج ما يلى:

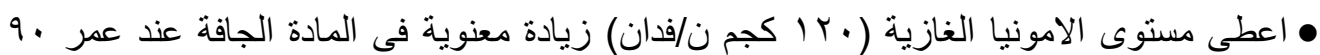

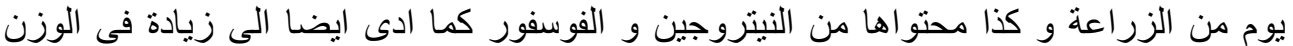

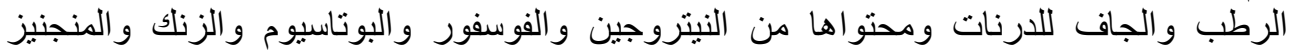

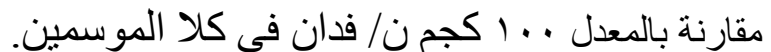

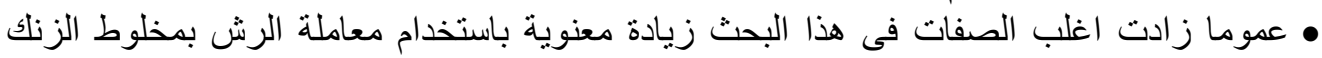

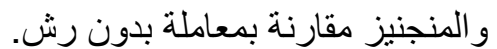

• سجلت أفضل قيم معنوية لمعظم الصفات باستخدام المعدل • با كجم ن /فدان والرش بمخلوط

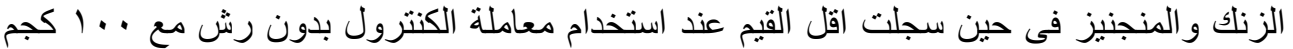
ن /فدان من الامونيا الغازية في كلا الموسمين.

Fayoum J. Agric. Res. \& Dev., Vol. 26, No.2, July, 2012 